\title{
Mötet mellan den statliga och kommunala kvalitetsstyrningen inom ramen för Samverkan för bästa skola
}

\author{
Carl-Henrik Adolfsson \\ Linnéuniversitetet \\ Jan Håkansson \\ Högskolan i Dalarna
}

\begin{abstract}
Inom ramen för det svenska decentraliserade skolsystemet har ansvaret för att bygga upp, utveckla och bedriva ett systematiskt kvalitetsarbete i första hand varit en fråga för huvudmän och skolor att hantera. I ljuset av en ökad re-centralisering av skolan har uppbyggandet av olika kvalitetssystem för uppföljning och kontroll av skolornas resultat också kommit att utgöra ett viktigt sätt för huvudmannen att styra skolan på. I studien benämns detta i termer av kvalitetsstyrning. I och med Samverkan för bästa skola har dessa gränsdragningar mellan det lokala och det nationella kommit att utmanas. Studien bygger på intervjudata inhämtad på fyra skolor som deltar i Samverkan för bästa skola, från skolförvaltningen i samma kommun samt genom intervju med en representant från Skolverket. Utifrån begreppen löst kopplade system och organisatoriska rutiner studeras vad som karaktäriserar den nationella respektive den kommunala kvalitetsstyrningen samt vad som sker i mötet dem emellan på skolor som genomgår insatser inom ramen för Samverkan för bästa skola, samt med vilka konsekvenser. Resultatet av studien visar bland annat på att idéer och metoder om databaserad skolutveckling utgör viktiga legitimitetsgrunder för såväl den kommunala som den nationella kvalitetsstyrningen. Den nationella kvalitetsstyrningen via Samverkan för bästa skola är dock betydligt mer intensifierad och når längre in i skolornas organisation.
\end{abstract}

\section{INLEDNING}

I skolsystem runt om i världen diskuteras hur skolors kvalitet kan utvecklas med syfte att förbättra elevers resultat och måluppfyllelse. Omfattande strukturella och läroplansrelaterade reformer i kombination med olika sätt att 
mäta elevers kunskapsnivåer har utvecklats. I ljuset av detta har samtidigt intresset för och kraven på skolor och huvudmän att utveckla olika system för resultatuppföljning och kvalitetsutveckling ökat. I början på 1990-talet genomgick det svenska skolsystemet en långtgående decentralisering där kommunala och fristående skolhuvudmän har möjlighet att utöva ett stort inflytande över skolorna i kombination med ett omfattande kvalitetsansvar i relation till måluppfyllelse och likvärdighet (Wahlström, 2002). Detta brukar benämnas den "dubbla styrningen", där staten genom lagstiftning, förordningar och direktiv, via ett antal statliga skolmyndigheter sätter upp olika kvalitetsstandarder i form av nationella mål och riktlinjer för skolor och förskolor. Huvudmannen, till exempel en kommun, har i sin tur i uppgift att dels skapa förutsättningar för att skolor och förskolor efterlever dessa nationella krav och mål, dels följa upp och åtgärda eventuella brister.

Med sjunkande elevresultat och en ökande bristande likvärdighet mellan skolor kom dock den svenska skolan och dess långtgående decentralisering att hårt kritiseras under 2000-talets första två decennier Adolfsson (2013). I linje med flera internationella policytrender, inte minst uppbackat av OECD, har detta resulterat i åtskilliga skolreformer där statens ambition har varit att ta ett starkare grepp om skolan och dess resultat. Denna policytrend kan urskiljas i flera länder och beskrivs ibland i termer av en 're-centralisering' (Wahlström \& Sundberg, 2017a; Adolfsson, 2018). För Sveriges vidkommande har denna policytrend kommit till uttryck på flera sätt: i) skollagen har reviderats där bland annat rektorernas inflytande och ansvar för den egna skolenheten har betonats och tydliggjorts i relation till huvudmannen, ii) i de nationella läroplanerna för grund- och gymnasieskolan från 2011 (Lgr 11, Lgy 11), återfinns, i jämförelse med de föregående läroplanerna, ett tydligare framskrivet innehåll samt kunskapskrav, iii) initieringen av en rad olika nationella kompetensutvecklingsinsatser för lärare, iv) det har inrättats en nationell myndighet för skolinspektion, liksom v) ett nationellt skolforskningsinstitut som ska bistå skolorna med evidensbaserade undervisningsmetoder samt vi) riktade statsbidrag som pekar ut och finansierar önskvärda och angelägna utvecklingsområden för skolorna.

Oavsett hur man ser på motiven bakom förändringarna är det rimligt att tänka sig att denna policyutveckling har inneburit konsekvenser för relationerna mellan staten, de lokala skolhuvudmännen samt skolorna $i$ allmänhet och för den lokala styrningen av skolan i synnerhet. I denna artikel sätts dessa relationer i fokus genom att undersöka vad som händer i mötet mellan skolans och kommunens lokala kvalitetsarbete samt det statligt initierade kvalitetsarbete som sker inom ramen för Samverkan för bästa skola (SBS). 


\section{En ökad resultatfokusering och en intensivare kvalitetsstyrning av den svenska skolan}

I ljuset av en ökad resultatfokusering i kombination med den ökade nationella reglering som diskuterades ovan, visar studier hur skolförvaltningar på kommunal eller distriktsnivå i flera länder utgör en viktig policyaktör, inte minst när det kommer till att koordinera och implementera nationell policy, följa upp skolors resultat $i$ relation till nationella mål och kunskapsstandarder, men också att sätta in stödjande insatser $\mathrm{i}$ de fall där kvaliteten visar sig bristande (Farrell \& Coburn, 2016; Seashore, 2013; Rorrer et al., 2008; Nordholm, 2016; Addi-Raccah, 2015; Spillane, 1996; Wahlström \& Sundberg, 2017a). Även Prøitz et al. (2019) pekar på en liknande utveckling: “One global policy trend in education is that of improving teaching and learning by assigning responsibility for educational change and improving students' learning outcomes at the municipal/district level" (Prøitz et al, 2019, s. 2).

Som en följd av detta har uppbyggnaden av olika lokala kvalitetssystem blivit ett allt viktigare sätt för den lokala skolhuvudmannen och skolorna att hantera nationella krav på måluppfyllelse och likvärdighet (Spillane, 2011; Adolfsson \& Alvunger, 2020). Wahlström och Sundberg (2017b) visar i sin studie av implementeringen av den svenska läroplanen för grundskolan 2011 att kopplingarna mellan den nationella nivån och huvudmännen i många fall var starka i synnerhet när det kom till bedömningsfrågor och betygskriterier. Däremot var kopplingarna svaga när handlade om områden som rörde skolors och huvudmäns systematiska kvalitetsarbete (Wahlström \& Sundberg, 2017b). Detta resultat går i linje med skollagens (SFS 2010:800) intentioner att organisering och genomförande av lokalt kvalitetsarbete är något som $i$ stor utsträckning ska överlämnas till skolor och huvudmän att hantera och ansvara för. Skollagen konstaterar endast att det ska bedrivas ett systematiskt kvalitetsarbete på såväl skol- som huvudmannanivå genom att planera, följa upp och utveckla utbildningen med inriktning mot de nationella målen. Detta innebär att denna typ av lokala kvalitetssystem kan vara uppbyggda och organiserade på olika sätt. På ett övergripande plan syftar de dock till att med utgångspunkt från de nationella målen formulera och tydliggöra kvalitetsstandarder, följa upp resultat samt identifiera utvecklingsbehov och initiera förbättringsinsatser. Detta angränsar till det som inom bland annat företagsekonomi och managementforskningen benämns som kvalitetsstyrning eller Total quality management (TQM) (Psychogios \& Priporas, 2007).

Begreppet kvalitetsstyrning kan ses som ett paraplybegrepp utan någon exakt teoretisk definition. Övergripande handlar det dock om att arbeta fram system och modeller för att kvalitetssäkra verksamhetens processer med syfte att optimera dess utfall. Lagrosen (1997) pekar ut tre grundläggande aspekter av denna kvalitetsstyrning som brukar betraktas som fundamentala: i) kundfokusering ii) alla medarbetares aktiva deltagande $i$ att effektivisera verksamheten iii) uppfattningen om att verksamhetens ständigt står under ett 
förändringstryck och därför alltid behöver utvecklas och förbättras. Utifrån de beskrivningar och rekommendationer som Skolverket skriver fram kopplat till skolans systematiska kvalitetsarbete finns vissa kopplingar till dessa aspekter (se t.ex. Skolverket, 2012). Exempelvis framhålls att det är elevernas lärande och utveckling, som alltid ska stå $\mathrm{i}$ fokus för skolans verksamhet, uppföljning och utveckling. Vidare betonas betydelsen av att all personal på skolan har ett ansvar för att utveckla verksamheten, individuellt och kollegialt. Till sist beskrivs också, utifrån Skolverkets rekommendationer, att skolans systematiska kvalitetsarbete ska förstås som en ständigt pågående cyklisk process innehållande olika faser där arbetet på ett systematiskt sätt går in i och bygger på varandra.

Med begreppet kvalitetsstyrning avses i denna studie den styrningsform som kännetecknas av hur en aktör, exempelvis en skolhuvudman, genom uppbyggnaden av olika kvalitetssystem, följer upp och kontrollerar olika former av resultat på skolorna. Men begreppet innefattar också, vilket blir viktigt i denna studie, hur samma aktör genom olika metoder, strategier och stödinsatser försöker kvalitetssäkra skolornas egna kvalitetssystem.

Det bedrivs en mycket omfattande forskning med koppling till just TQM. Inte sällan har dessa studier till syfte att försöka utveckla och effektivisera olika metoder och system för verksamheters kvalitetsutveckling och kvalitetssäkring (Bejeroth \& Hasselbladh, 2002). I denna artikel är det dock fenomenet som sådant, som det kommer till uttryck i mötet mellan den statliga och den lokala kvalitetsstyrningen på fyra grundskolor, som utgör intresset.

\section{Ansvaret för skolans systematiska kvalitetsarbete}

I enlighet med 1990-talets långtgående decentralisering av den svenska skolan har det svenska skolsystemet sedan dess byggt på en tydlig mål- och resultatstyrning. Grundprincipen är att staten sätter upp nationella mål som skolorna sedan ska arbeta efter att uppnå. Skolhuvudmannen ska i sin tur ge skolorna de förutsättningar som krävs för detta arbete. Frågor kopplat till skolans processer, såsom undervisning och utveckling av undervisning, kom således i stor utsträckning att överlämnats till skolan och huvudmannen att ansvara för. Ansvaret för att bygga upp, utveckla och bedriva ett systematiskt kvalitetsarbete har därför, såsom ovan nämndes, $i$ första hand varit en fråga för huvudmannen och skolorna:

Varje huvudman inom skolväsendet ska på huvudmannanivå systematiskt och kontinuerligt planera, följa upp och utveckla utbildningen (Skollagen, kap $43 \S$ ). 
Sådan planering, uppföljning och utveckling av utbildningen som anges i

$3 \int$ ska genomföras även på förskole- och skolenhetsnivå (Skollagen, kap 4,4 ).

2015 initierades dock av regeringen en omfattande nationell satsning under namnet "Samverkan för bästa skola" (SBS) (U2015/3357/S) som i vissa avseenden kan ses utmana denna ansvarsordning. Under ledning av Skolverket, är syftet med denna satsning att med riktade insatser mot huvudmän, skolor och förskolor erbjuda olika former av stöd. Vilka skolor och huvudmän som erbjuds att delta i satsningen bygger på Skolinspektionens granskningar. Även om insatserna kan variera beroende på huvudmännens och skolornas specifika behov handlar dessa i allmänhet om att öka kvaliteten på undervisningen genom att stärka skolornas och huvudmannens kvalitetssystem och ledningsfunktioner: "Vårt uppdrag är att genom riktade insatser stärka förskolan, skolan och huvudmannen $i$ arbetet med att planera, följa upp och utveckla utbildningen efter deras unika mål och behov" (www.skolverket.se/skolutveckling/leda-och-organisera-skolan/samverkanfor-basta-skola).

Mot bakgrund av ovanstående kan den av regeringen initierade insatsen SBS ses som ett uttryck och tillika exempel på en sådan form av statlig kvalitetsstyrning och där de två statliga skolmyndigheterna Skolinspektionen och Skolverket således utgör två viktiga aktörer i denna styrning. Genom SBS har därmed staten tagit ett steg in på ett ansvarsområde som tidigare i första hand varit en fråga för skolan och skolhuvudmannen att ansvara för och hantera. Om detta är en önskvärd utveckling eller inte är en politisk fråga, men oavsett det är det rimligt att tänka sig att relationerna och gränsdragningen mellan statens, kommunernas och skolornas ansvarsområden utmanas. På vilket sätt och framförallt med vilka konsekvenser är en empirisk fråga som också står i fokus för denna artikel.

\section{Syfte och frågeställningar}

Studien som ligger till grund för den här artikeln har genomförts i anslutning till ett pågående treårigt forskningsprojekt där vi följer en grundskoleförvaltnings kvalitetsstyrning av grundskolorna $i$ en större kommun i Sverige. Fyra av skolorna i denna kommun har samtidigt genomgått insatser inom ramen för Samverkan för bästa skola. Med detta följde således en möjlighet att på nära håll studera vad som sker i mötet mellan den statliga och den kommunala kvalitetsstyrningen av skolan, vilket också har varit syftet med denna studie.

Följande forskningsfrågor stod i fokus för studien:

- Vad karaktäriserar den kommunala respektive den statliga kvalitetsstyrningen av skolan? 
- Hur uppfattar och hanterar representanter från Skolverket, skolhuvudmannen och skolorna relationen och mötet mellan den statliga och den kommunala kvalitetsstyrningen inom ramen för Samverkan för bästa skola?

- Vilka konsekvenser får den statliga kvalitetsstyrningen för skolornas och huvudmannens lokala kvalitetsarbete?

\section{Implementering, sammankopplande processer och organisatoriska rutiner - studiens teoretiska ram}

Det finns inom reform- och skolförbättringsforskningen en lång historik av studier om utbildningspolicy och dess möjligheter och tillkortakommanden när det gäller att påverka skolor, lärare och undervisning. Frågan om hur man ska förstå extern reglering och reformimplementering samt dess eventuella genomslag och konsekvenser $\mathrm{i}$ skolan har studerats utifrån flera olika perspektiv. Utifrån ett traditionellt top-down perspektiv förstås implementeringsprocessen som en teknisk och rationell process vilket innebär att analysen primärt riktats mot reformens ursprungliga intentioner och i vilken grad dessa får, eller inte får, verkningar i den aktuella verksamheten. Implementeringsmisslyckanden ses utifrån ett sådant perspektiv främst som en teknisk fråga där fokus riktas mot reformers utformning och reformstrategier (Fixsen et al., 2005). Som en kontrast till detta perspektiv har bottom-up orienterade ansatser i större utsträckning kommit att fokusera på de professionellas, de så kallade "street-level bureaucrats", situation, kunskaper och intentioner som en viktig och avgörande faktor för att förstå reformimplementering (se t.ex. Lipsky, 1980).

De senaste decenniernas forskning om skolreformer har alltmer försökt att se bortom denna dikotomi i termer av top-down och bottom-up. När det kommer till att skapa långsiktiga och hållbara förändringar i skolan framhålls istället betydelsen av att olika nivåer eller lager i skolsystemen samspelar och rör sig i samma riktning (Cuban, 2013; Håkansson \& Sundberg, 2016). För att förstå frågor kopplat till styrning, reformering och implementering har det därför blivit viktigt att få en förståelse för hur skolan som organisation är konstituerad samt hur dess externa och interna relationer fungerar (Spillane et al. 2011; Adolfsson \& Alvunger, 2017). I detta sammanhang har begrepp som löst kopplade, frikopplade och starkt kopplade system lyfts fram som ett sätt att rikta fokus mot karaktären på relationerna mellan en organisations olika delsystem, i termer av exempelvis hierarkiska nivåer, funktioner eller grupper (Orton \& Weick, 1990). Utifrån en sådan teoribildning blir således kopplingarna mellan dessa delsystem centrala men också hur de påverkas av och förhåller sig till andra organisationer samt omgivande villkor. Begreppet "koppling" blir i denna teoribildning central och inrymmer således både dimensioner av avstånd och närhet inom organisationen och dimensioner av öppenhet och slutenhet i relation till omvärlden. Denna syn på organisationer 
som bestående av olika, och i vissa fall motsatta, typer av relationer innebär att kopplingar kan betraktas som processer och inte som egenskaper som en viss organisation "har". En organisation där flera eller delar av kopplingarna mellan organisationens olika delsystem är starka kan delsystemen beskrivas som att vara 'responsiveness without distinctiveness', det vill säga det finns en mottaglighet för extern påverkan samtidigt som gränserna mellan organisationens olika delsystem inte är så starka och distinkta. I löst kopplade system kännetecknas kopplingarna mellan delsystemen vara 'both responsiveness and distinctiveness' vilket innebär att också dessa system ses som öppna för förändring och extern påverkan men att det råder tydliga distinktioner mellan de olika delsystemen. I organisationer där kopplingarna mellan delsystemen karaktäriseras som frikopplade från varandra brukar däremot beskrivas som 'distinctiveness without responsiveness', det vill säga att det råder tydliga och distinkta gränser mellan delsystemen i kombination med att dessa inte är särskilt mottagliga för externt förändringstryck (Orton \& Weick, 1990, s. 205).

Med en sådan begreppsapparat följer att intresset riktas mot när, och på vilka sätt, lösa kopplingar blir tydliga och när, och hur, det är möjligt att i stället se tecken på starkare kopplingar. Allt det har betydelse för hur man i sin tur ska förstå policyprocesser, implementering och extern reglering av skolan. En bättre förståelse för organisationens olika delsystem och karaktären på dess kopplingar möjliggör en bättre förståelse för exempelvis implementeringsprocessen kopplad till en utbildningsreform och dess grad av genomslag på en skola. Lösa kopplingar eller frikopplingar mellan delsystemen inom ett skolsystem brukar exempelvis ses som en förklaring till den svårighet som utbildningsreformer har att få de effekter som är önskvärda (Spillane et al., 2011).

Mot bakgrund av detta kan den re-centraliseringsrörelse som inledningsvis diskuterades förstås som ett sätt för staten att försöka stärka kopplingarna mellan skolsystemets olika nivåer och med detta få nationella mål att nå ända in i klassrummet och därigenom få bättre kontroll över skolans resultat. I ljuset av en sådan teoribildning kan således såväl Samverkan för bästa skola som huvudmannens kvalitetsstyrning uppfattas ha sådana sammankopplade ambitioner i termer av att genom de olika aktiviteter och strategier som ryms inom ramen för den aktuella kvalitetsstyrningen, försöka knyta skolans verksamhet starkare till sig.

Utifrån en sådan förståelse av styrning och policyimplementering följer således en ambition att synliggöra hur dessa sammankopplande aktiviteter kommer till uttryck på skolnivå genom den kommunala respektive den statliga kvalitetsstyrningen. I studien studeras vad huvudmannen respektive staten, via de insatser och aktiviteter som sker inom ramen för Samverkan för bästa skola, innehållsligt fokuserar och försöker påverka samt förändra med avseende på skolornas organisation och tillhörande processer. Ett begrepp 
som möjliggör en sådan analys är organisatoriska rutiner (Feldman \& Pentland, 2003; Becker, 2004; Spillane, et al., 2011; Spillane, 2012). Med begreppet organisatoriska rutiner fokuseras organisationens strukturer $\mathrm{i}$ form av de regelbundenheter av beteenden och handlingar som finns i en organisation, eller som Feldman och Pentland (2003) uttrycker det: “...a repetitive, recognizable pattern of interdependent actions, involving multiple actors" (s. 311). Med begreppet organisatoriska rutiner kan således de mönster och rutiner som återfinns $\mathrm{i}$ en organisations dagliga arbete synliggöras. I en skolorganisation skulle detta kunna innefattas av olika former av möten såsom arbetslagsmöten, ledningsmöten, skolutvecklingsmöten, elevrådsmöten, utvecklingssamtal osv, men också aktiviteter kopplat till det systematiska kvalitetsarbetet såsom insamling av underlag, resultatanalyser, lärares kollegiala lärande etc.

I litteraturen om organisatoriska rutiner brukar två aspekter av den organisatoriska rutinen lyftas fram. Med den ostensiva aspekten avses de formella, schematiska, eller om man så vill, de tänkta strukturerna i en organisation. Syftet med de ostensiva rutinerna är främst att skapa en förutsägbarhet $\mathrm{i}$ arbetet och dessutom förutsättningar för specifika och önskvärda aktiviteter, som exempelvis ett arbetslags analysarbete kopplat till elevernas kunskapsresultat. Med den performativa aspekten avses istället den "levda" organisationen i form av människors aktiviteter, interaktion och handlingar som sker mellan människor i relation till de ostensiva rutinerna: "specific actions, by specific people, in specific places and at specific times. It is the routine in practice" (Feldman \& Pentland, 2003, s. 101).

Med begreppet organisatoriska rutiner är syftet i denna studie att synliggöra karaktären på den statliga respektive den kommunala kvalitetsstyrningen men också vad i skolornas organisation som styrningen fokuserar och försöker påverka. I enlighet med Spillane et al. (2011) kan en sådan ansats motiveras som att:

While there is a sizable literature showing that external regulations get inside schools and even beyond the classroom door, we know much less about how these regulations become embodied in the formal school structure (s. 588).

Mer konkret handlar analysen således om att, via skolaktörers erfarenheter, uppfattningar och förståelse av SBS och den kommunala kvalitetsstyrningen, dels studera vilka organisatoriska rutiner som byggs upp inom ramen för den kommunala respektive den statliga kvalitetsstyrningen. Dels hur samma aktörer uppfattar och beskriver vilka av de ostensiva och performativa aspekterna av skolornas organisation som fokuseras och prioriteras via denna kvalitetsstyrning. Med detta möjliggörs slutligen att peka på såväl skillnader 
mellan den nationella och den lokala styrningen och vad som sker i mötet dem emellan.

\section{Metod och material}

Den empiri som ligger till grund för denna studie samlades in i nära anslutning till ett treårigt forskningsprojekt vars övergripande syfte var att studera den lokala kvalitetsstyrningen av skolan. Forskningsprojektet i sin helhet bedrevs genom så kallad följeforskning i en svensk skolkommun, där vi över tid på nära håll studerade grundskoleförvaltningens utvecklande av ett kvalitetssystem för resultatuppföljning och kvalitetsförbättring kopplat till kommunens grundskolor. Följeforskningen är flexibel och formativ i sitt upplägg vilket innebar att man som forskare över en längre tid och på nära håll följer det som avses att studeras. Även om man som forskare inte ingår i de processer som studeras ingår i följeforskningens upplägg att kontinuerligt återkoppla de resultat och tolkningar som görs till de aktörer som ingår i studien (Patton, 2015). Detta sätt att arbeta har gett ett unikt tillträde till sammanhang och empiriska data som hade varit svåra att få tillgång till genom en mer traditionell forskningsdesign.

Föreliggande studie utgör således en delstudie till ovanstående forskningsprojekt. Datainsamlingen har skett genom intervjuer av skolaktörer på olika nivåer i skolsystemet, en del genom gruppintervjuer och en del genom individuella intervjuer. För att få kunskaper om den kommunala kvalitetsstyrningen har personal vid den aktuella kommunens grundskoleförvaltning (utbildningschefer, ledningsstöd för kvalitet och utveckling) intervjuats. Ett strategiskt urval tillämpades där personer med god kunskap om kommunens kvalitetsarbete och resultatuppföljning valdes ut. För att på motsvarande sätt få en förståelse för den statliga kvalitetsstyrningen såsom den kommer till uttryck genom SBS har en intervju genomförts med en representant från Skolverket. Vederbörande var en av två så kallade processstödjare vilket innebar ett ansvar för de specifika SBS-insatserna i den aktuella kommunen. För studiens syfte var det viktigt att de representanter från Skolverket som intervjuades hade god insyn i kommunens och de aktuella SBS-skolornas resultat, utvecklingsbehov och planerade insatser. Av praktiska skäl var det inte möjligt att intervjua de båda processtödjarna från Skolverket, vilket hade stärkt det totala empiriska underlaget. Även om detta kan ses som en svaghet i studien, menar vi att den längre intervju som genomfördes med en av processtödjarna gav tillgång till rik information, fördjupning och problematisering utifrån ett statligt perspektiv. För att få en bild av hur den kommunala respektive den statliga kvalitetsstyrningen i sin tur kom till uttryck på skolorna samt med vilka konsekvenser, har rektorer och lärare vid de aktuella SBS-skolorna på motsvarande sätt intervjuats.

Kopplat till vårt teoretiska ramverk riktades intresset mot dessa aktörers erfarenheter och förståelse av såväl de ostensiva som de performativa 
aspekterna av de organisatoriska rutinerna som fokuserades inom ramen för SBS. Nedan följer en sammanställning av genomförda intervjuer:

Tabell 1. Sammanställning av studiens empiriska material

\begin{tabular}{|l|l|l|}
\hline Målgrupp & Metod & Fokus \\
\hline $\begin{array}{l}\text { Processtödjare } \\
\text { Skolverket (n=1) }\end{array}$ & $\begin{array}{l}\text { Semistrukturerad } \\
\text { individuell intervju }\end{array}$ & $\begin{array}{l}\text { Erfarenheter kopplade till } \\
\text { styrningsstrategier nationellt och } \\
\text { lokalt/relationen stat-huvudman-SBS- } \\
\text { skola }\end{array}$ \\
\hline $\begin{array}{l}\text { Utbildningsdirektör } \\
(\mathrm{n}=1)\end{array}$ & $\begin{array}{l}\text { Semistrukturerad } \\
\text { individuell intervju }\end{array}$ & $\begin{array}{l}\text { Erfarenheter kopplade till } \\
\text { styrningsstrategier nationellt och } \\
\text { lokalt/relationen stat-huvudman-SBS- } \\
\text { skola }\end{array}$ \\
\hline $\begin{array}{l}\text { Utbildningschefer } \\
(\mathrm{n}=6)\end{array}$ & $\begin{array}{l}\text { Semistrukturerade } \\
\text { individuella } \\
\text { intervjuer }\end{array}$ & $\begin{array}{l}\text { Erfarenheter kopplade till } \\
\text { styrningsstrategier nationellt och } \\
\text { lokalt/relationen stat-huvudman-SBS- } \\
\text { skola/ledningsstöd till SBS-rektorer }\end{array}$ \\
\hline $\begin{array}{l}\text { Representanter för } \\
\text { kommunens } \\
\text { övergripande lednings- } \\
\text { och kvalitetsstöd (n=4) }\end{array}$ & $\begin{array}{l}\text { Semistrukturerade } \\
\text { individuella } \\
\text { intervjuer }\end{array}$ & $\begin{array}{l}\text { Erfarenheter kopplade till } \\
\text { styrningsstrategier nationellt och } \\
\text { lokalt/mötet mellan lokal } \\
\text { kapacitetsmodell och nationell } \\
\text { skolförbättringsstrategi }\end{array}$ \\
\hline $\begin{array}{l}\text { Rektorer och } \\
\text { biträdande rektorer på } \\
\text { 4 SBS-skolor (n=9) }\end{array}$ & $\begin{array}{l}\text { Semistrukturerade } \\
\text { gruppintervjuer }\end{array}$ & $\begin{array}{l}\text { Erfarenheter kopplade till } \\
\text { styrningsstrategier nationellt och } \\
\text { lokalt/relationen stat-huvudman-SBS- } \\
\text { skola/ledarskap och SKA på en SBS- } \\
\text { skola }\end{array}$ \\
\hline $\begin{array}{l}\text { Nyckelpersoner/lärare } \\
\text { med särskilt ansvar för } \\
\text { skolans kvalitetsarbete } \\
\text { (n=19) }\end{array}$ & $\begin{array}{l}\text { Semistrukturerade } \\
\text { gruppintervjuer }\end{array}$ & $\begin{array}{l}\text { Erfarenheter kopplade till } \\
\text { styrningsstrategier nationellt och } \\
\text { lokalt/lärdomar kring det lokala SKA, } \\
\text { undervisningen och elevernas lärande }\end{array}$ \\
\hline
\end{tabular}

Varje intervju omfattade ungefär 60 minuter. Dessa spelades in, avlyssnades och transkriberades. Totalt omfattar det skriftliga intervjumaterialet cirka 120 sidor. De semistrukturerade intervjuerna vägleddes av en intervjuguide som hade delvis olika frågor beroende på vilka respondenter som intervjuades. Frågorna var dock ordnade tematiskt utifrån tre huvudområden i) skolans alternativt huvudmannens kvalitetssystem ii) uppfattningar om relationen stat-kommun-skola med avseende på styrning, kvalitet och kvalitetsarbete iii) uppfattningar och erfarenheter av Samverkan för bästa skola.

Analysen av det empiriska materialet genomfördes i tre steg. I ett första steg studerades det transkriberade materialet explorativt, iterativt och oberoende av var och en av forskarna. Med utgångspunkt i studiens forskningsfrågor, identifierades och jämfördes i ett andra steg de preliminära innehållsliga mönster $\mathrm{i}$ form av kategorier som vuxit fram men också variationer kopplat till de tre tematiska huvudområdena. Det blev bland annat 
tydligt utifrån utsagorna på såväl förvaltnings- som skolnivå att uppfattningarna varierade om betydelsen av Samverkan för bästa skola i allmänhet och de genomförda nulägesanalyserna på skolorna i synnerhet. I ett tredje steg analyserades dessa mönster i ljuset av studiens teoretiska ramverk. Detta innebar att de kategorier, mönster och variationer som identifierades i det första och andra analyssteget med avseende på statens respektive huvudmannens kvalitetsstyrning analyserades utifrån studiens begreppsapparat i termer av kopplade system och organisatoriska rutiner (Bryman, 2012).

\section{RESULTAT}

I detta avsnitt redogörs för resultaten av studien med utgångspunkt från de frågeställningar som inledningsvis presenterades. I första steget diskuteras vad som kännetecknar karaktären på den kommunala kvalitetsstyrningen. Det vill säga på vilket sätt och med vilka strategier försöker huvudmannen, via sitt kvalitetssystem, styra och stötta skolorna? Motsvarande fråga behandlas i relation till den statliga kvalitetsstyrningen, såsom den kommer till uttryck på de skolor där Samverkan för bästa skola genomfördes. I ett nästa steg diskuteras vad som i sker i mötet mellan den nationella och den kommunala kvalitetsstyrningen på skolnivå, det vill säga vilka konsekvenser får samverkan för bästa skola för skolornas och huvudmannens kvalitetsarbete och inte minst för relationen dem emellan?

\section{Den kommunala kvalitetsstyrningen}

Organisatoriska rutiner kopplade till uppfölining och kommunikation av skolornas resultat

Vid intervjuer med grundskoleförvaltningens personal framträder en tydlig bild av att det kvalitetssystem som huvudmannen hade byggt upp och arbetade efter i relation till skolorna i stor utsträckning byggde på idén om så kallad databaserad skolutveckling. Det vill säga, uppföljning av skolors kvalitet och resultat samt identifiering av skolors utvecklingsbehov och beslut om skolutvecklingsinsatser ska grundas på säkra underlag och en noggrann analys. Med detta följde att grundskoleförvaltningens kvalitetssystem i stora drag var uppbyggt kring ett antal formella organisatoriska rutiner där data kontinuerligt samlades in, analyserades och sen kommunicerades med skolorna: "Ett av valspråken är att vi styr genom uppföljning genom att vi samlar in underlag" (Utredningssekreterare 1).

För att grundskoleförvaltningen skulle kunna erhålla tillförlitliga underlag kopplat till skolornas kvalitet och resultat byggde detta på att skolorna i sin tur och på motsvarande sätt byggde upp egna välfungerande interna kvalitetssystem. Genom att grundskoleförvaltningen var tydlig med vilka resultat vederbörande var intresserade av och skulle komma att följa upp 
skickades en tydlig signal till skolorna vad dessa, inom ramen för sitt systematiska kvalitetsarbete, behövde fokusera på i sitt interna uppföljningsoch analysarbete:

I samband med skolornas kvalitetsrapporter skickar vi ju en signal om vad vi vill att de ska följa upp, det är ju en tydlig styrning, vi vill att ni tittar på de här resultaten ... Det är ju en tydlig styrning (Utvecklingsstrateg 1, grundskoleförvaltningen).

Detta innebar således en formalisering och standardisering av såväl grundskoleförvaltningens som skolornas uppföljning och analys av resultaten. I detta ingick också att från grundskoleförvaltningens sida även till viss del styra vilka underlag som skolorna skulle analysera:

Tidigare har vi sagt att det är bra om ni följer upp utifrån läroplanens mål men nu är vi mer inne på att vi i större utsträckning väljer ut vilken data som ska analyseras - titta på den här och den här datan (Utbildningschef 1 , grundskoleförvaltningen).

I utvecklingen av grundskoleförvaltningens kvalitetssystem beskrevs att det också hade skett en ökad formalisering av innehållet i kommunikationen mellan grundskoleförvaltningen och skolorna. Denna kommunikation kring skolornas resultat och kvalitet sker primärt genom fyra så kallade kvalitetsdialoger där ansvarig utbildningschef från förvaltningen träffar skolledningen och ibland också ett urval av lärarna vid respektive skola. Vid dialogerna sker ett samtal och en uppföljning av skolornas resultat utifrån fyra olika på förhand bestämda innehållsområden:

Jämfört med tidigare är det nu en betydligt högre grad av formalisering och konsensus mellan utbildningscheferna på förvaltningen, vilka frågor vi ska ställa $\ldots$ det är viktigt för att det sen ska vara möjligt att aggregera resultaten, det var knappt möjligt förut (Utbildningschef 2, grundskoleförvaltningen).

Det var dock inte enbart elevresultaten som stod i fokus för dessa kvalitetsdialoger utan lika mycket vilka insatser som ska initieras och prioriteras på skolan samt på vilka grunder och utifrån vilka analyser som dessa beslut hade fattats. Men även kvaliteten på skolornas kvalitetssystem och ledningsfunktioner diskuterades och behandlades inom ramen för dessa dialoger. Precis som de frågor som ställdes $i$ anslutning till skrivandet av respektive skolas kvalitetsrapport avsåg således dessa dialoger inte enbart att följa upp vissa resultat utan också att stötta och utveckla skolornas organisatoriska rutiner relaterat till det interna systematiska kvalitetsarbetet. Det vill säga genom de frågor som ställdes av representanter från grundskoleförvaltningen 
styrde man också skolornas kvalitetsarbete i en viss önskvärd riktning: “... skolorna vet vilka frågor vi kommer att ställa, vid kvalitetsdialogerna. På detta sätt styr vi ju skolornas datainsamling och deras analysarbete" (Utbildningschef 3, grundskoleförvaltningen).

Även om skolförvaltningen, i enlighet med Skollagen (2010:800) inte har någon regulativ makt med avseende på att bestämma hur rektor ska organisera sitt kvalitetsarbete, sina ledningsfunktioner eller vilka prioriteringar de behöver göra så fanns ändå en tydlig strävan att skapa en koherens mellan förvaltningens och skolornas kvalitetssystem. Exempelvis fanns en ambition att motsvarande kvalitetsdialoger som genomfördes mellan förvaltningen och skolledningen, skulle genomföras av rektorerna med den pedagogiska personalen utifrån samma innehållsliga fokus:

Vi tänker att få in motsvarande dialoger på skolnivå istället för medarbetarsamtal. Få in det på fler nivåer. Varje medarbetare möter sin närmaste chef fyra gånger per år utifrån ramverket och pratar utifrån sitt arbete, utifrån sig själv (Utvecklingsstrateg 1, grundskoleförvaltningen).

\section{Organisatoriska rutiner kopplade till fortbildning och rekrytering}

Förvaltningens kvalitetssystem byggde således på en idé om att formalisera och standardisera processer kopplat till insamling av data, analys och kommunikation kring skolornas resultat och kvalitet. En viktig del i arbetet med att uppnå den koherens och samsyn inom hela skolorganisationen kopplat till ovanstående bestod i att samtliga rektorer hade fått genomgå en omfattande ledarskapsutbildning med fokus på databaserad skolutveckling. En liknande utbildning, fast med ett systemfokus, hade grundskoleförvaltningens personal på ett motsvarande sätt genomgått. I samtalen med såväl rektorerna som förvaltningens personal återkom man och hänvisade ofta till denna utbildningsinsats vilket kan tyda på att den fått ett stort genomslag i organisationen. I citatet nedan beskriver exempelvis en rektor hur denna ledarskapsutbildning på många skolor inneburit ett ökat fokus på insamlingen av olika sorters data:

... det finns en ambition att använda en annan data också. Genom ledarskapsutbildningen har man ju uppmuntrat oss ta in så mycket data som möjligt och då inte bara använda en typ, utan öppna upp för annan data också (Rektor, Skola 3).

En ytterligare strategi för grundskoleförvaltningen vad gäller att utveckla en koherens inom organisationen men också att skapa ett hållbart kvalitetssystem bestod i att rekrytera rätt rektorer. I intervjuerna på grundskoleförvaltningen framhölls det som viktigt att de rektorer som tillsattes på nya tjänster hade de kunskaper som ansågs nödvändiga för att kunna arbeta inom organisationens 
kvalitetssystem men kanske framförallt att vederbörande var "lojala" mot systemet som sådant:

Vi för ju rätt omfattande diskussioner när vi ska jobba i en samma struktur, så blir det viktigt att fundera på vilka rektorer som vi ska rekrytera. Det går ju inte att komma som rektor och tro att man ska kunna frifräsa, det går ju inte. Rekrytering blir ju ett viktigt sätt, man måste tänka in det att det harmonierar med ramverket (Utvecklingsstrateg 2, grundskoleförvaltningen).

Sammanfattningsvis kännetecknades den kommunala kvalitetsstyrningen av att huvudmannen, genom sitt kvalitetssystem, utvecklat ett antal organisatoriska rutiner som syftade till att följa upp och kommunicera skolornas resultat. Integrerat i denna resultatuppföljning fanns också en styrningssträvan i form av en ambition att stötta och tillika utveckla skolornas interna organisatoriska rutiner kopplat till skolornas lednings- och kvalitetssystem. I detta sammanhang utgjorde rektorn en central aktör.

\section{Den statliga kvalitetsstyrningen via Samverkan för bästa skola}

Förenande för de insatser som sker inom ramen för Samverkan för bästa skola är att samtliga är organiserade utifrån en och samma formaliserade arbetsmodell, framtagen av Skolverket. Det arbete som sker inom ramen för denna modell, i form av olika utvecklingsinsatser, varierar dock beroende på skolornas eller huvudmannens utvecklingsbehov. Alla insatser, inkluderat de fyra skolor som stått $\mathrm{i}$ fokus för denna studie, inleds med en fördjupad nulägesanalys. Denna nulägesanalys leds av Skolverkets processtödjare och pågår under 6-8 månader med syftet att på ett fördjupat och systematiskt sätt identifiera orsakerna till skolans (bristande) resultat. Liksom i kommunens kvalitetssystem är denna arbetsmodell tydligt grundad i en idé om databaserad skolutveckling där insamling och analys av olika former av underlag utgör ett fundament:

Vi ägnade mycket tid åt att få fram material som vi kunde analysera, vi hade ett väldigt stort underlag och att vi fick stöd $i$ vårt systematiska kvalitetsarbete, att inte nöja sig med att jag tror det ser ut så här utan vi måste veta..."jag tror" var bannlysta ord (Rektor skola 4).

Efter den genomförda nulägesanalysen, och i enlighet med den struktur som arbetet i Samverkan för bästa skola följer, upprättas en åtgärdsplan där man mot bakgrund av resultatet från analyserna beskriver vilka insatser som ska genomföras på skolan. I detta steg kopplas även ett lärosäte på som tillsammans med skolan, under cirka två år, ska arbeta med de identifierade utvecklingsbehoven. 


\section{Insatser inriktade på undervisningsnära organisatoriska rutiner}

På de fyra skolorna som stod i fokus för studien handlade det primärt om olika former av handledning och stöd för att stärka och tydliggöra skolans ledningsstrukturer, skolans arbets- och utvecklingsorganisation samt att stärka kapaciteten och organisationen kring det systematiska kvalitetsarbetet:

De insatser vi kommer fram till inom ramen för SBS det handlar ju många gånger om handledning av nåt slag, nån slags processledning professionshandledning. Att ställa frågor som gör att man reflekterar på olika nivåer över sitt arbete sin verksamhet (Processtödjare, Skolverket).

På de fyra skolor som ingick i denna studie utgjorde en viktig del av respektive insats att utveckla och stärka det distribuerade ledarskapet på skolorna. Detta framhöll samma processtödjare som extra viktigt, inte minst på skolor med stora utvecklingsbehov. Konkret innebar det att utveckla skolans organisation kopplat till de så kallade mellanledarna, (exempelvis förstelärare och arbetslagsledare) och att tydliggöra deras funktioner och uppdrag kopplat till skolans systematiska kvalitetsarbete. Men också att via processhandledarutbildningar, stärka dessa mellanledares kapacitet att leda sina lärarkollegor:

... det går inte att bara ha en bra skolledning. Man måste komplettera det med en kader av mellanledare som kan distribuera ledarskapet och i allra bästa fall gynnar det ett ansvarstagande och en ansvarskultur också på lärarnivå så att vi bygger en organisation som är mindre sårbar (Processtödjare, Skolverket).

Vid sidan av att stärka organisationen och ledarskapet på skolorna genomfördes på de undersökta skolor insatser som på ett mer direkt sätt hade fokus på att utveckla undervisningskvaliteten i klassrummet. Dessa didaktiskt orienterade fortutbildningsinsatser kunde se lite olika ut. På en av skolorna arbetade man exempelvis med en allmändidaktisk kompetensutvecklingsinsats riktad till samtliga lärare medan det på en annan skola var fokus mer specifikt på det språkutvecklande arbetssättet. På ytterligare en annan skola arbetade man aktivt med att bygga upp en struktur kring att arbeta med lärarcoacher och lesson studies:

Det som kännetecknar arbetet på skolan är utifrån det vi egentligen hade identifierat som problem innan Skolinspektionen kom är det som sker i klassrummet. Så det som sker som insatser är kopplade till det ... Språkutvecklande arbetssätt, processledare som leder det arbetet, utveckla lärarnas lärande, kollegialt lärande (Skolledare, Skola 3). 
Som kommer att diskuteras mer ingående i följande avsnitt framhöll flera av skolans aktörer att det kanske viktigaste som Samverkan för bästa skola bidrog med var pengar. Pengar som i sin tur möjliggjorde men också påskyndade skolornas interna utvecklingsarbeten. På grund av Skolinspektionens, $\mathrm{i}$ många fall, skarpa yttranden mot de skolor som deltog $\mathrm{i}$ studien var skolledningen tillsammans med huvudmannen $i$ flera fall mitt uppe i planeringen av ett omfattande utvecklingsarbete när beslut fattades att dessa skolor skulle gå in i Samverkan för bästa skola. Mot bakgrund av detta beskrev några rektorer att man inte enbart var positiv till att gå in i en sådan här nationell satsning. Däremot framhölls att en viktig motivationsfaktor ändå var de ekonomiska resurser som följde med Samverkan för bästa skola. Dessa såg man kunde stärka det utvecklingsarbete som i flera fall redan hade initierats på skolorna:

Vid uppstartsmötet, där hade rektorerna lite olika ingångar till det här. Jag tänkte bara dollartecken, här kommer pengarna! (Rektor, skola 3)

Sen har pengarna möjliggjort saker, vi hade ju alla de här tankarna och allt det här hade vi gjort ändå, utan SBS, men det skulle ta längre tid. Pengarna har gjort att vi kunnat göra saker mycket snabbare och dra igång processer mycket snabbare (Lärare, skola 3).

Vid sidan av detta framhölls att Skolverket men också det lärosäte som var inblandat $\mathrm{i}$ insatsen också utgjorde en betydelsefull auktoritet. Denna auktoritet skapade i sin tur legitimitet för skolornas förändringsarbete, både externt $\mathrm{i}$ relation till huvudmannen, men inte minst internt $\mathrm{i}$ relation till personalen på skolorna:

Det har inneburit en annan legitimitet bland kollegiet. Det finns psykologi i det, den feedback vi fătt från Skolverket, där de bekräftar hur bra vi jobbar och hur genomtänkt det är. Ger bekräftelse på att vi gör rätt (lärare, Skola 3).

En ytterligare viktig aspekt som bidrog till att SBS-insatserna i flera fall beskrevs ha hög legitimitet på skolorna var att insatsen involverade inte enbart skolledningen utan en större del av skolans personal. Detta bidrog till att de utvecklingsområden som identifierades genom de initiala nulägesanalyserna samt de insatser som initierades var väl förankrade bland skolans personal.

\section{SBS - en intensifierad och mer djupgaende kvalitetsstyrning}

I en jämförelse mellan den kommunala och den statliga kvalitetsstyrningen, såsom det kom till uttryck $\mathrm{i}$ denna studie, uppvisades både likheter och skillnader. På en övergripande nivå återfanns en liknande ambition dem emellan att genom ambitionen att påverka och stödja skolornas egna 
kapacitetsbyggande stärka kopplingarna mellan nivåerna i skolsystemet. En viktig strategi i detta kopplingsarbete, både vad gäller den nationella och den kommunala kvalitetsstyrningen, bestod i att följa upp och analysera skolornas resultat och genom detta utveckla och stärka skolornas organisation och processer kopplat till skolornas ledningsfunktioner och det systematiska kvalitetsarbetet. I både den kommunala och den statliga kvalitetsstyrningen utgjorde idén om en databaserad skolutveckling ett fundament.

Ytterligare en likhet mellan kommunens kvalitetsarbete och Samverkan för bästa skola var dess starka fokus på skolledarskapet. I båda fallen sågs rektorn som en viktig förändringsagent vilket innebar att de också stod i centrum för både den nationella och den kommunala kvalitetsstyrningen. Även det distribuerade ledarskapet på skolorna framhölls såväl av representanter från kommunen som Skolverket som strategiskt viktigt att utveckla, inte minst med syftet att få en ökad spridning och legitimitet för kvalitetsarbetet på skolorna. Skillnaderna var dock, som diskuterades i föregående avsnitt, att SBS i flera fall hade direkta insatser på skolorna som syftade till att utveckla just denna typ av ledarskap.

En annan skillnad mellan den kommunala och den nationella kvalitetsstyrningen, som också uppmärksammades i föregående avsnitt, var de resurser som följde med SBS:

Och vissa av insatserna hade vi inte hoppat på så snabbt, till exempel coachning i undervisning, för vi hade inte haft pengar. Det är mycket pengar det kostar och det tror jag inte skolledningen hade tagit beslut på ... hade vi inte haft Skolverket hade vi nog inte hoppat på det (Lärare 4, Skola 3).

De resurser som kopplades till insatserna inom ramen för SBS möjliggjorde att arbetet blev mer djupgående, nådde längre in i skolans organisation och var på ett mer direkt sätt riktade mot skolornas kärnverksamhet, det vill säga undervisningen: "Det var mycket mer rakt på med SBS, det var språkutveckling och klassrumsdidaktik som det skulle handla om och vi skulle följa den här modellen" (Skolledare, skola 2).

Det vill säga den kvalitetsstyrning som skedde inom ramen för Samverkan för bästa skola beskrevs som mer intensifierad men också mer formaliserad i jämförelse med huvudmannens kvalitetsarbete, som framhölls som mer generellt till sin karaktär: "Det är mer 'pin-pointat' i SBS ... förvaltningen är mer generell i sitt arbete" (Lärare, skola 3). I samtal med representanter från huvudmannen diskuterades hur vederbörande såg på denna skillnad. I flera fall uppmärksammades då det spänningsförhållande och ibland otydliga gränser som finns mellan å ena sidan huvudmannens övergripande ansvar för likvärdighet och skolornas kvalitet samt resultat, å andra sidan rektorns självbestämmande och ansvar för sin skolas resultat, inre organisation och sitt 
kvalitetsarbete: “Nä, den gränsdragningen är inte tydlig. Just här $\mathrm{i}$ vår kommun. Det är inget tydligt land. Och det kanske inte går att sålla upp. Men jag tror den behöver tydliggöras" (Utredningssekreterare 1, utbildningsförvaltningen).

Denna gränsdragningsproblematik verkade skapa en viss osäkerhet hos huvudmannen med avseende på vad och hur långt huvudmannen kunde gå i sin kvalitetsstyrning. Ett exempel på detta utgjordes av de fall där skolorna inte uppvisade de resultat som var önskvärda och hur långt förvaltningen då kunde gå i sin styrning och kontroll $\mathrm{i}$ relation till rektorns ansvar. Ett annat exempel rörde kvaliteten på skolornas organisation, där förvaltningen hade identifierat ett stort utvecklingsområde men där det till viss del rådde delade meningar om hur långt huvudmannen kunde gå i sin kvalitetsstyrning:

$\mathrm{Nu}$ i arbetet framåt med huvudmannens och skolornas kvalitetsarbete ... man har pratat om att man ska titta på hur skolorna ska rigga sina arbetsorganisationer. Jag kan förstå det /.../ organisationen är en jätteviktig aspekt. Samtidigt styr rektor över sin organisation och vi kan inte förespråka standardlösning, eller där vi presenterar en lösning för skolorna, varsågoda! Så funkar det inte ... (Utredningssekreterare 2).

Denna gränsdragning som återfinns mellan huvudmannens och rektors ansvarsområden kan således tillsammans med resurserna utgöra en förklaring till de skillnader som förelåg mellan den kommunala och den nationella kvalitetsstyrningen. SBS-insatserna beskrevs som mer specifika och som nådde längre in i skolans kärnverksamhet till skillnad från huvudmannens kvalitetsstyrning som beskrevs som mer generell till sin karaktär och som ofta enbart riktad mot skolledningen. Mot bakgrund av detta avses att $i$ ett nästa steg diskutera hur detta möte mellan den kommunala och den nationella kvalitetsstyrningen uppfattades av aktörerna på de olika nivåerna i skolsystemet.

\section{Mötet mellan den kommunala och den statliga kvalitetsstyrningen}

Skolverkets och skolornas organisatoriska rutiner kopplat till identifiering av utvecklingsbehov

I samtalen med rektorerna på de undersökta skolorna framkom en mångfacetterad bild av hur det arbete som genomfördes inom ramen för SBS förhöll sig gentemot det 'ordinarie' kvalitetsarbetet som skedde på skolorna i relation till huvudmannen. Detta gällde exempelvis det initiala och tämligen omfattande analysarbete som skedde under ledning av Skolverkets processstödjare, där en omfattande analys av skolornas nulägen gjordes mot bakgrund av Skolinspektionens tillsyns- och granskningsbeslut. Vissa skolledare såg detta arbete som något konstruktivt, som möjliggiorde dels en 
fördjupad analys av skolornas faktiska utvecklingsbehov, dels en ökad möjlighet att involvera flera av skolans lärare i skolans analysarbete:

Framförallt fick vi mycket stöd i att tänka kring våra underlag och borra och tänka på effekter och våra egna målformuleringar /.../ Men det var väldigt nyttigt, det var också utvecklande för ledningsgruppen och för våra förstelärare som var med i utvecklingsgruppen (Skolledare, skola 4).

På andra skolor mottogs motsvarande arbete inte lika positivt. Skolledarna menade att ett liknande analysarbete redan hade gjorts, tillsammans med personal från skolförvaltningen, omedelbart efter att Skolinspektionens beslut hade blivit kända. Skolledarna menade därför att man på skolan och hos huvudmannen redan mycket väl visste vilka utmaningar som fanns på skolan. I dessa fall beskrevs också att det redan hade initierats ett utvecklingsarbete på skolorna med ett bra stöd av huvudmannen:

Med Skolinspektionen visste vi ... vi hade giort en stor analys tillsammans med personalen och grundskoleförvaltningen. Och sen kom SBS och då skulle vi göra om allt detta. Så i våra ögon tappade vi ett år (Rektor, skola 1).

Dessa rektorer uppfattade således att det redan fanns fungerande rutiner på skolan och hos huvudmannen kopplat till det systematiska kvalitetsarbetet. SBS:s modell och arbete med skolornas nulägesanalyser uppfattades i dessa fall således inte kunna bidra med något nytt. Men även om skolledningen på några av skolorna riktade en del kritik mot detta "dubbelarbete" var dock lärarna på samma skolor betydligt mer positiva till Skolverkets analysarbete. Lärarna framhöll bland annat att de upplevde sig mycket delaktiga i Skolverkets nulägesanalyser, jämfört med hur fallet ofta var vid det 'ordinarie' kvalitetsarbetet då motsvarande djupgående analyser framförallt skedde mellan skolledningen och grundskolechefen från förvaltningen. Denna ökade delaktighet $\mathrm{i}$ analysarbetet menade de hade resulterat $\mathrm{i}$ att utvecklingsarbetet nu blev mer förankrat bland skolans personal:

Det var ju ett långt processande, det var väldigt många träffar då vi skulle borra neråt neråt ... men det fanns en vinning med och det såg jag inte förrän vi hade gått igenom hela proceduren. Nu är det väldigt väl förankrat inte bara hos oss utan också hos våra kollegor, vad är det vi behöver utveckla (Lärare, skola 1).

Detta motstånd och tveksamhet från vissa av skolledarna var också något som representanterna från Skolverket noterade. Det blev tydligt att den standardiserade modell för hur en insats inom ramen för samverkan skulle genomföras inte riktigt passade alla de skolor i kommunen som deltog i SBS: 
... rektorerna var ganska långt fram i ett tänkande kring det här och det här och det här måste vi göra, de var ganska handlingsfokuserade och hade handlingsplaner klara eller på gång. Och där fick ju vi problem kan jag säga, för vi hade ju en modell vi ville jobba efter. Så när vi sa att vi ska göra en inventering av problemen ... men vi vet redan vad som är problemet sa de här rektorerna (Processtödjare, Skolverket).

\section{Den nationella kvalitetsstyrningen som överordnad den kommunala}

I och med att en skola går in i SBS så innebär det, som diskuterades inledningsvis, ett intensivt och långvarigt arbete tillsammans med Skolverket och ett lärosäte. En central fråga som uppkommer är hur detta arbete förhåller sig till huvudmannens kvalitetsarbete. På frågan om hur skolans rektorer och lärare såg på just denna relation beskrevs det i många fall som att SBS $\mathrm{i}$ viss utsträckning kom att ta över det kvalitetsarbete som skolan $i$ annat fall skulle ha bedrivit i samverkan med huvudmannen:

Rektor 1) ... den utbildningschef som vi hade initialt höll en extremt låg profil i SBS-arbetet.

Intervjuare) Kan man säga att förvaltningen till viss del backade när SBS sattes igång?

Rektor 1) ... och släppte in SBS, de fick ta över, jaa ... jag tror inte riktigt heller man hade koll på vad SBS var.

Rektor 2) Men det är det som SBS kommer med. De kommer med en modell och en pengapåse och det tackar man ju inte nej till från förvaltningen, det förstår jag också ....

På förvaltningsnivån i den aktuella kommunen var man generellt sett mycket positivt till SBS. Inte minst utbildningscheferna, som arbetade direkt mot rektorerna och skolorna, framhöll insatserna inom ramen för SBS som givande och något som i stor utsträckning låg $i$ linje och harmonierade med förvaltningens kvalitetsarbete. Samtidigt var man öppen med att framhålla betydelsen av att SBS bidrog med resurser men också med kompetens. Dock kunde en viss ambivalens urskiljas bland annan personal på förvaltningen vad gäller just att staten under lång tid kommer in och arbetar direkt mot skolorna kring områden som egentligen kan ses utgöra huvudmannens ansvar:

Hade jag inte vetat något så hade jag sett att det inte är bra att köra parallella processer men samtidigt har vi ju inspirerats mycket från SBS. Så lite kluven är jag. Vi är ju en stor huvudman så vi har ju resurser så då kanske vi inte ska ha någon utifrån, i projekt. Utan vi ska skapa egna rutiner och vanor (Utvecklingsstrateg, Grundskoleförvaltningen). 
En rektor ställde sig på motsvarande sätt frågande varför SBS-insatserna egentligen riktades mot skolorna och inte enbart mot huvudmannen. Vederbörande menade att det ytterst borde vara huvudmannens ansvar att se till att stödja skolor så det inte gick så långt att de behövde stöd genom Skolverket och SBS:

Men jag har aldrig hört att huvudmannen sagt att det här är vårt fel, här har vi inte stöttat tillräckligt /.../Sen får vi i uppgift - ordna upp detta! SBS skulle egentligen in på huvudmannanivå och inte på skolnivå. Då hade det fått bättre effekt. Nu blir det väldigt skuldbeläggande på skolan. Men vad gör då huvudmannen? (Rektor, Skola 3).

När motsvarande fråga diskuterades med processtödjaren från Skolverket betonade vederbörande därför vikten av att involvera huvudmannen i arbetet med skolorna. Principiellt såg representanten från Skolverket dock inga problem att staten gjorde insatser direkt på skolor. Tvärtom menade samma processtödjare att staten ytterst måste fungera som en garant för att eleverna får den kvalitet på sin utbildning som de har rätt till enligt skollagen:

Resultaten på skolan är ju grunden för att de blir utvalda tillsammans med det som Skolinspektionen identifierar som bristområden ... Jag tycker det är nåt slags skyddsnät som är helt rimligt att staten ska kunna stå för. Huvudmannen har ju väldigt olika utmaningar (Processtödjare).

Mot bakgrund av ovanstående, där mötet mellan den kommunala och den nationella kvalitetsstyrningen har diskuterats är det tydligt hur en insats som SBS på många sätt utmanar och omdefinierar gränsdragningarna staten, huvudmannens och skolans handlingsutrymme och ansvarsområde. Detta kommer att diskuteras vidare $i$ artikeln avslutande diskussion.

\section{DiSKUSSION}

I denna avslutande diskussion kommer studiens frågeställningar att lyftas och diskuteras i ljuset av artikelns resultat och teoretiska ramverk. I ett första steg redogörs för vad som karaktäriserar såväl den nationella som den kommunala kvalitetsstyrningen och dess legitimitetsgrunder men också vilka skillnader som kan urskiljas dem emellan. Med utgångspunkt från detta diskuteras avslutningsvis vilka konsekvenser som mötet mellan den nationella och den lokala kvalitetsstyrningen får för skolors och huvudmäns kvalitetsarbete men också vad det innebär för de gränsdragningar som finns mellan det nationella och det lokala inom ramen för det decentraliserade skolsystemet. 


\section{Kvalitetsstyrningens karaktär och dess legitimitet}

Med begreppet kvalitetsstyrning riktades i denna studie fokus på hur staten via Skolverket respektive skolhuvudmannen, genom olika kvalitetssystem följer upp och kontrollerar skolors resultat, men också hur man med olika strategier och aktiviteter försöker kvalitetssäkra skolornas egna kvalitetssystem. Som resultaten i denna studie har visat skedde detta i stor utsträckning genom uppbyggandet av olika formella system, i termer av organisatoriska rutiner. För huvudmannens vidkommande handlade det till exempel om olika system för resultatuppföljning med länkade kvalitetsdialoger där det skedde en kommunikation mellan skola och huvudman om skolornas resultat och kvaliteter, utifrån vissa förutbestämda teman. Inom ramen för SBS återfanns det motsvarande väl utvecklade och formaliserade organisatoriska rutiner kopplat till exempelvis genomförandet av skolornas nulägesanalyser. I såväl den nationella som den kommunala kvalitetsstyrningen ingick också att försöka påverka skolans interna organisatoriska rutiner bland annat kopplat till deras kvalitetsarbete och ledningsfunktioner (Spillane et al., 2011).

I den svenska skollagen (2010:800) framhålls att det är rektorn som ansvarar för sin inre organisation, resursfördelning samt för skolans resultat och utveckling av verksamheten. Med detta följer att såväl den kommunala som den nationella kvalitetsstyrningens karaktäriseras primärt av att vara ickeregulativ till sin uppbyggnad (jfr Scott, 1995). Det vill säga i kvalitetsstyrningen finns inga eller $i$ alla fall få legala eller tvingande element med tillhörande sanktionsmöjligheter. Som resultaten i denna studie påvisat karaktäriseras den istället av att vara uppbyggd av en "mjukare" styrningslogik med i huvudsak normativa och diskursiva inslag (jfr Adolfsson \& Alvunger, 2020). Denna styrning kom till uttryck i form av olika ostensiva organisatoriska rutiner som möjliggjorde olika aktiviteter, det vill säga den performativa aspekten av motsvarande rutiner, $i$ termer av exempelvis resultatuppföljning, kvalitetsdialoger, samverkan mellan rektorer, samt jämförelser mellan skolor osv. Däremot kan denna "mjukare" styrning ses erhålla legitimitet och indirekt vara uppbackad av mer regulativa element såsom skollag, läroplaner, yttranden från Skolinspektionen osv. Om en skola hade en tydlig negativ resultatutveckling eller fått skarpa yttranden från Skolinspektionen är det därför rimligt att tänka sig att det vore svårt för en rektor att tacka nej till stöd och insatser från huvudmannen eller staten.

Ytterligare en viktig legitimitetsgrund för såväl den kommunala som den statliga kvalitetsstyrningen var därtill att många av dess aktiviteter, som exempelvis kvalitetsdialoger, analyser, identifiering av utvecklingsbehov samt val av insatser, byggde på en systematisk insamling och analys av olika former av data. Detta fokus och tillika idén om att systematiskt använda data som grund för beslutsfattande kan förstås $i$ ljuset av en bredare internationell policytrend, men också ett forskningsfält, som brukar benämnas 'Data based 
decision making' (DBDM) (se t.ex. Schildkamp, 2019; Sun et al., 2016; Hoogland et.al, 2016). I denna strävan att genom ett systematiskt förfarande med avseende på insamling och analys av data, fatta rationella och välgrundade beslut, finns en bakomliggande idé om evidensbasering (jfr Prøitz et al, 2019). Det är tydligt att såväl den kommunala som den nationella kvalitetsstyrningen, i val av metoder och innehåll, sökte legitimitetsgrund från just en sådan tanke om evidens.

\section{Kvalitetsstyrningens sammankopplande ambitioner och frikopplande konsekvenser}

Som diskuterades inledningsvis förstås såväl den kommunala som den nationella kvalitetsstyrningen utifrån ett perspektiv där implementering och policy ses som försök att stärka kopplingarna mellan nivåerna och olika delsystem. I denna studie handlade det om en strävan att stärka kopplingarna mellan de nationella målen, skolornas kvalitetsarbete och den undervisning som sker på skolan, men också om att i vissa fall stärka kopplingarna mellan delsystemen inom ramen för en skolas interna organisation, till exempel mellan skolledningen och arbetslagen. I enlighet med tidigare forskning (Wahlström \& Sundberg, 2017a) utgjorde skolhuvudmannen i denna studie en viktig policyaktör både vad gäller att översätta, koordinera och implementera nationella policybeslut men också på det sätt som samma huvudman, via sitt kvalitetssystem, följde upp och kommunicerade kring skolors resultat samt på olika sätt försökte stärka skolornas egen förbättringskapacitet.

Samverkan för bästa skola kan, med de resurser som följer med en sådan insats, ses som en kraftfull åtgärd för att stärka kopplingarna mellan den nationella nivån och den lokala skolan. Även om dessa insatser sker i nära dialog med skolhuvudmannen påvisade våra resultat att flera av skolans aktörer uppfattade det som att SBS i viss utsträckning kom att ta över centrala delar av huvudmannens kvalitetsarbete. Konsekvensen blev, som resultatet också visade, att huvudmannen $\mathrm{i}$ den aktuella kommunen $\mathrm{i}$ någon mån uppfattades inta en passiv roll i relation till den nationella insatsen. Detta innebar att även om kopplingarna mellan den nationella nivån och den lokala skolan stärktes genom SBS så fanns det en risk för att kopplingarna mellan huvudman och skolorna försvagades. Även om detta knappast är syftet med SBS, utan snarare tvärtom, pekar detta på vikten av att huvudmannen involveras $\mathrm{i}$ insatserna och betraktas som en jämbördig part gentemot den nationella nivån.

Som namnet på SBS antyder är det någon form av samverkan mellan olika aktörer som eftersträvas inom ramen för insatserna. Mot bakgrund av diskussionen ovan uppkommer dock frågan vad det är för slags samverkan som konstitueras genom SBS. Det är en fråga som skulle kräva en mer fördjupad analys men noterbart är att det är en samverkansform som är tydligt 
top-down initierad. Det vill säga, det är en samverkan som förväntas ske inom, på förhand givna ramar med avseende på vilka som ska samverka med vem och hur denna samverkan ska gå till samt kring vilket innehåll. Samverkan, såsom den kommer till uttryck inom ramen för SBS, blir med detta en viktig del av den statliga kvalitetsstyrningen.

\section{Den nationella kvalitetsstyrningens accentuering - nya gränsdragningar inom ramen för det decentraliserade skolsystemet?}

Som diskuterades ovan kännetecknades såväl den kommunala som den nationella kvalitetsstyrningen av att vid sidan av att följa upp resultat också med olika strategier och aktiviteter försöka påverka och stötta skolornas organisatoriska rutiner kopplade till skolans egna kvalitetssystem, ledningsorganisation men också undervisningen. En viktig skillnad mellan den nationella kvalitetsstyrningen såsom den kom till uttryck genom Samverkan för bästa skola och den kommunala, bestod i att den förstnämnda beskrevs som mer intensifierad och något som kom att arbeta sig längre in $\mathrm{i}$ skolans organisation och i dess kärnverksamhet. Skillnaden kan beskrivas i termer av de organisatoriska rutinernas ostensiva respektive performativa aspekter. Den kommunala kvalitetsstyrningen stannade i stor utsträckning vid att följa upp resultat och genom olika former av dialoger ställa frågor till $i$ huvudsak skolledningen om respektive skolas ostensiva rutiner, i synnerhet kopplat till skolans systematiska kvalitetsarbete. Med andra ord, huvudmannen vill följa upp och säkra kvalitetssäkra dessa rutiner. Den nationella kvalitetsstyrningen, genom SBS, gick dock genom sina insatser betydligt längre och arbetade inte enbart med skolans ostensiva organisatoriska rutiner. Istället var de under lång tid i hög grad inriktade mot, samt involverade $i$, de processer och de aktiviteter som skedde inom ramen för dessa ostensiva rutiner som exempelvis processledarutbildningar och utveckling av undervisningen. Det vill säga, det som kan benämnas som de performativa aspekterna av de organisatoriska rutinerna.

Skolans systematiska kvalitetsarbete har, i enlighet med det decentraliserade skolsystemets utgångspunkter, länge definierats som primärt en lokal angelägenhet och en fråga för rektor och skolhuvudmannen att hantera. Som resultatet i denna studie pekar på kan den nationella satsningen SBS i viss mån utmana denna ansvarsfördelning. Som policyfenomen kan därför SBS förstås i ljuset av en accelererande re-centraliseringsrörelse, där vi sett en utveckling mot en ökad statlig reglering och kontroll av skolan med syftet att ta ett starkare grepp över skolans resultat samt likvärdighet. Om detta är en önskvärd utveckling eller inte ser vi främst som en politisk fråga. Däremot är det rimligt att anta relationerna mellan staten, huvudmannen och skolan utmanas. Med detta följer att kartan över ansvarsfördelningen och gränsdragningarna dem emellan till viss del ritas om, med en successiv 
omdefiniering av innebörden av det decentraliserade skolsystemet som konsekvens.

\section{REFERENSER}

Addi-Raccah, Audrey (2015). School principals' role in the interplay between the superintendents and local education authorities: The case of Israel. Journal of Educational Administration, 53, 287-306.

Adolfsson, Carl-Henrik, \& Alvunger, Daniel (2020). Power dynamics and policy actions in the changing landscape of local school governance. Nordic Journal of Studies in Educational Policy, 6(2), 128-142.

Adolfsson, Carl-Henrik (2018). Upgraded curriculum? An analysis of knowledge boundaries in teaching under the Swedish subject-based curriculum. Curriculum Journal, 29(3), 424-440.

Adolfsson, Carl-Henrik, \& Alvunger, Daniel (2017). The nested systems of local school development: Understanding improved interaction and capacities in the different sub-systems of schools. Improving Schools, 20(3),195-208.

Adolfsson, Carl-Henrik (2013). Kunskapsfrägan: En läroplansteoretisk studie av den svenska gymnasieskolans reformer mellan 1960-talet och 2010-talet (Doktorsavbandling). Linnaeus University Press.

Becker, Markus (2004) Organizational routines. A review of the literature. Industrial and Corporate Change, 13(4), 643-677.

Bejeroth, Eva, \& Hasselbladh, Hans (2002). Kvalitet utan gränser: en keritisk belysning av kvalitetsstyrning. Academia Adacta.

Bryman, Alan. (2012). Social research methods (4. uppl.) Oxford University Press.

Cuban, Larry (2013). Inside the black box of classroom practice: change without reform in American education. Harvard Education Press.

Farrell, Caitlin, \& Coburn, Cynthia (2016). Absorptive capacity: A conceptual framework for understanding district central office learning. Journal of Educational Change, 18(2), 135-159.

Feldman, Martha, \& Pentland, Brian 2003. Reconceptualizing organizational routines as a source of flexibility and change. Administrative Science Quarterly, 48, 94 118.

Fixsen, Dean, Naoom, Sandra, Blase, Karen, Friedman, Robert, \& Wallace, Frances (2005). Implementation Research: A Synthesis of the Literature. University of South Florida.

Håkansson Jan, \& Sundberg, Daniel (2016). Utmärkt skolutveckling: Forskning om skolförbättring och måluppfyllelse. Natur \& Kultur. 
Hoogland, Inge, Schildkamp, Kim, Van Der Kleij, Fabienne, Heitink, Maaike, Kippers, Wilma, Veldkamp, Bernard, \& Dijkstra, Anne. M. (2016). Prerequisites for data-based decision making in the classroom: Research evidence and practical illustrations. Teaching and Teacher Education, 60, 377-386.

Lagrosen, Stefan (1997). Kvalitetsstyrning i skolan? En analys av TQM:s tillämpbarbet inom den svenska grundskolan sett frän en företagsekonomisk utgaingspunkt (Doktorsavhandling). Stockholms Universitet.

Lipsky, Michael (1980). Street-level bureaucracy - Dilemmas of the individual in public services. Russell Sage Foundation.

Nordholm, Daniel (2016). State policy directives and middle-tier translation in a Swedish example. Journal of Educational Administration, 54(4), 393-408.

Orton, Douglas, \& Weick, Karl (1990). Loosely coupled systems: A reconceptualization. The Academy of Management Review, 15(2), 203-223.

Patton, Michael (2015). Qualitative research \& evaluation methods: Integrating theory and practice (4. uppl.). SAGE Publications.

Psychogios, Alexandros, \& Priporas, Constantinos-Vasilios (2007). Understanding Total Quality Management in Context: Qualitative Research on Managers Awareness of TQM Aspects in the Greek Service Industry. The Qualitative Report, 12(1), 40-66.

Prøitz, Tine, Mausethagen, Sölvi, \& Skedsmo, Guri (2019). District administrators' governing styles in the enactment of data-use practices. International Journal of Leadership in Education. DOI:10.1080/13603124.2018.1562097.

Rorrer, Andrea, Skrla, Linda, \& Scheurich, James (2008). Districts as institutional actors in educational reform. Educational Administration Quarterly, 44, 307-358.

Schildkamp, Kim (2019). Data-based decision-making for school improvement: Research insights and gaps. Educational Research, 61(3), 257-273.

Scott, Richard (1995). Institutions and organizations. SAGE.

Seashore, Karen (2013). Districts, local education authorities, and context of policy analysis. Journal of Educational Administration, 51(4), 550-555.

Svensk författningssamling (2010:800). Skollag. Sveriges Riksdag.

Skolverket (2012). Allmänna råd med kommentarer om systematisk.t kvalitetsarbete för skolväsendet. Fritzes.

Spillane, James (1996). School districts matter: Local educational authorities and state instructional policy. Educational Policy, 10(1), 63-87.

Spillane, James (2012). Data in Practice: Conceptualizing the Data-Based DecisionMaking Phenomena. American Journal of Education, 118(2), 113-141.

Spillane, James, Parise, Leigh, \& Sherer, Jennifer (2011). Organizational routines as coupling mechanisms: Policy, school administration, and the technical core. American Educational Research Journal, 48, 586-619. 
Sun, Jingping, Przybylski, Robert, \& Johnson, Bob (2016). A review of research on teachers' use of student data: from the perspective of school leadership. Educational Assessment Evaluation and Accountability, 28(1), 5-33.

U2015/3357/S. Uppdrag om samverkan för bästa skola. Utbildningsdepartementet.

Wahlström, Ninni, \& Sundberg, Daniel (2017a). Transnational curriculum standards and classroom practices. The new meaning of teaching. Routledge.

Wahlström, Ninni, \& Sundberg, Daniel (2017b). Kommuner som aktörer $i$ utbildningsreformer: implementeringen av läroplansreformen Lgr 11 (Rapport 2017:21). Institutet för arbetsmarknadspolitisk utvärdering (IFAU).

Wahlström, Ninni (2002). Om det förändrade ansvaret för skolan: Vägen till mål- och resultatstyrning och några av dess konsekvenser (Doktorsavhandling). Örebro Studies in Education 3. 